\title{
EFFECT OF TWO NON-STEROIDAL ANTIFERTILITY AGENTS ON PREGNANCY IN MICE
}

\section{COMPARISON OF IN-VITRO AND IN-VIVO EFFEGTS ON ZYGOTES}

\author{
JOAN L. THOMSON \\ King Ranch Laboratory of Reproductive Physiology, School of Veterinary Medicine, \\ Department of Animal Biology, University of Pennsylvania, Philadelphia
}

(Received 31st January 1967)

\begin{abstract}
Summary. The antifertility effects of two non-steroidal compounds, clomiphene and a diphenylindene derivative (U-11555A), were studied in the mouse, using two different methods. First, the effects of various concentrations of the compounds on the in-vitro development of two-cell mouse embryos into blastocysts were investigated. Second, the oral doses of the compounds which were necessary to block pregnancy in mice were determined. It was found that the inhibitory doses for mice are somewhat higher than for rats. Although it is impossible to make direct comparisons between the effective in-vivo and in-vitro doses, the inhibitory concentrations seem to be of nearly the same order in both cases.
\end{abstract}

\section{INTRODUCTION}

The use of certain non-steroidal compounds as oral antifertility agents in animals has been the subject of several recent investigations. The compounds include a group synthesized by the Merrell Company (MER-25 and clomiphene, MRL-41) and a group produced by the Upjohn Company (U-11555A, U-10520A and U-11100A). Most of the investigations have involved the antifertility effects of injected or oral doses during the first few days of pregnancy in the rat (Barnes \& Meyer, 1962; Davidson, Schuckner \& Wada, 1965; Duncan, Stucki, Lyster \& Lednicer, 1962; Nelson, Davidson \& Wada, 1963; Segal \& Nelson, 1961). During this period the zygotes are undergoing cleavage and blastocyst formation, while being transported through the oviduct to the uterus, in preparation for implantation. At present, there is disagreement among investigators as to whether these compounds act directly on the embryo, affect the rate of tubal transport or interfere with implantation.

The present study involves two of the compounds mentioned above: clomiphene, which is a triphenylethylene derivative, and U-11555A, which is a diphenylindene derivative. The purpose of the investigation was two-fold: 
first, to determine the effects of various single and multiple oral doses of the two compounds on pregnancy in the mouse, and to compare these with the effects on other species; and second, to compare the doses required to block pregnancy in vivo with the doses which prevent the in-vitro development of two-cell embryos into blastocysts.

\section{MATERIALS AND METHODS}

\section{Determination of dose response in vitro}

Two-cell embryos were obtained from superovulated random-bred Swiss adult mice. The animals were given 10 i.u. pregnant mare serum gonadotrophin (Gestyl, Organon) intraperitoneally, followed $48 \mathrm{hr}$ later by the injection of 10 i.u. human chorionic gonadotrophin (Pregnyl, Organon). After the second injection females were placed with males and were checked the next morning for vaginal copulation plugs. Twenty-four hours later the oviducts were aseptically removed from the pregnant mice, and the two-cell embryos were collected by flushing the tubes with culture medium (Brinster, 1963, 1965).

For experiments with U-11555A the eggs were cultured in small drops (approximately $0.1 \mathrm{ml}$ ) of medium under $10 \mathrm{ml}$ light-weight paraffin oil in $15 \times 60 \mathrm{~mm}$ plastic tissue culture dishes. During culture the dishes were kept at $37^{\circ} \mathrm{C}$ in an atmosphere of humidified $5 \% \mathrm{CO}_{2}$ in air. Under these conditions most two-cell embryos develop normally and form blastocysts after 3 days in culture.

For experiments involving clomiphene, a different culture system had to be utilized, because of the high solubility of the compound in paraffin oil. The two-cell embryos were placed in $3 \mathrm{ml}$ of medium in $12 \times 100 \mathrm{~mm}$ test tubes. The spaces between the medium and the tops of the tubes were filled with $5 \% \mathrm{CO}_{2}$ in air, and the tubes were closed with rubber stoppers and placed in an incubator at $37^{\circ} \mathrm{C}$. This method of culturing is far less satisfactory than the paraffin oil system in regard to the percentage of embryos forming blastocysts, but is the best of all the other methods without oil which were tried. A major disadvantage is that the contents of each tube must be poured into a watch glass in order to score the experiment.

For both compounds, preliminary experiments were carried out, using a wide range of doses, in order to determine the general region of effective concentrations for further testing. In later experiments, doses of both agents followed a geometrical progression of two. In all experiments twelve embryos were placed in each drop or test tube, and two drops or tubes were allotted to each treatment. At the end of 3 days of culture, the experiments were scored by counting the number of normal blastocysts which had developed from the two-cell embryos. The fractional score from each drop or tube was converted to an angle, and the transformed data were examined by an analysis of variance (Biggers \& Brinster, 1965).

\section{Determination of dose response in vivo}

In order to obtain large numbers of mice at the same stage of pregnancy, virgin Swiss female mice, 7 to 8 weeks old, were hormonally synchronized. 
Two i.u. PMSG were given intraperitoneally, and, $48 \mathrm{hr}$ later, 2 i.u. HCG were administered. Following the second injection, mice were placed with Swiss males, and were checked for copulation plugs the next morning.

Each experiment consisted of eight treatments, and ten pregnant mice were randomly allotted to each treatment, using random numbers. The mice were maintained as eight separate groups during the 4-day treatment period, but at the end of this time, they were re-randomized into four large cages, where they remained until slaughter 1 week later. Identification of the treatment groups was possible through the use of ear punching.

Gavaging was carried out, using $1-\mathrm{ml}$ plastic syringes with 22 gauge needles which were inserted into $2 \mathrm{~cm}$ lengths of Teflon tubing (Becton, Dickinson and Co., I.D. 0.026, O.D. 0.056). By placing the end of the tubing behind the tongues and partially down the throats of the animals they could easily be forced to swallow the small amounts of fluid delivered from the syringe. The mice used all weighed approximately $25 \mathrm{~g}$, and the dosage given was $0 \cdot 1 \mathrm{ml} /$ mouse. All solutions were made up in water, and control animals were gavaged with distilled water.

Preliminary experiments were designed to determine the range of effective antifertility doses of each compound. In later experiments, four treatment groups were given single doses, at four different concentrations, on Day 2. The other four groups were given quadruple doses, on Days 1 to 4 , with concentrations one-quarter those of the one-dose groups.

All the mice were killed on Day 10 of pregnancy, and the experiment was scored by counting the number of implantation sites, including foetuses which were being resorbed or had aborted. The percentage of pregnant mice in each group was converted to an angle, and the transformed data examined by an analysis of variance. The mean angular responses for the treatments were used to compare treatments with each other and with controls, utilizing a $t$-test. In addition, the mean number of implantation sites per pregnant mouse was determined for each treatment group, and the standard deviations were calculated.

\section{RESULTS}

\section{Determination of dose response in vitro}

The results of the in-vitro studies with clomiphene and U-11555A are presented in Tables 1 and 2, along with portions of the analyses of variance. The mean responses for the clomiphene experiment are lower than those for the U-11555A experiment because of the less efficient culture system which must be used. More than two replications were done with U-11555A because the first two experiments showed a large variation in treatment effect.

For both compounds, the doses range from one which is not significantly different from the control to one which completely prevents blastocyst formation (the lowest inhibitory dose). In the clomiphene experiments, cleavage of the embryos occurred at all of the concentrations used. Even at the highest dose tested $(0.8 \mu \mathrm{g} / \mathrm{ml})$ most of the embryos cleaved at least twice in culture. 
In the highest dose of U-11555A $(20 \mu \mathrm{g} / \mathrm{ml})$ however, only two of the ninety-six embryos treated cleaved at all; the others were all degenerated two-cell embryos at the end of the 3 days. Both of these concentrations represent the lowest inhibitory doses of the two compounds, as closely as was determined.

Determination of dose response in vivo

The effects of orally administered clomiphene and U-11555A on pregnancy in mice are presented in Tables 3 and 4, and graphically in Text-fig. 1. In these

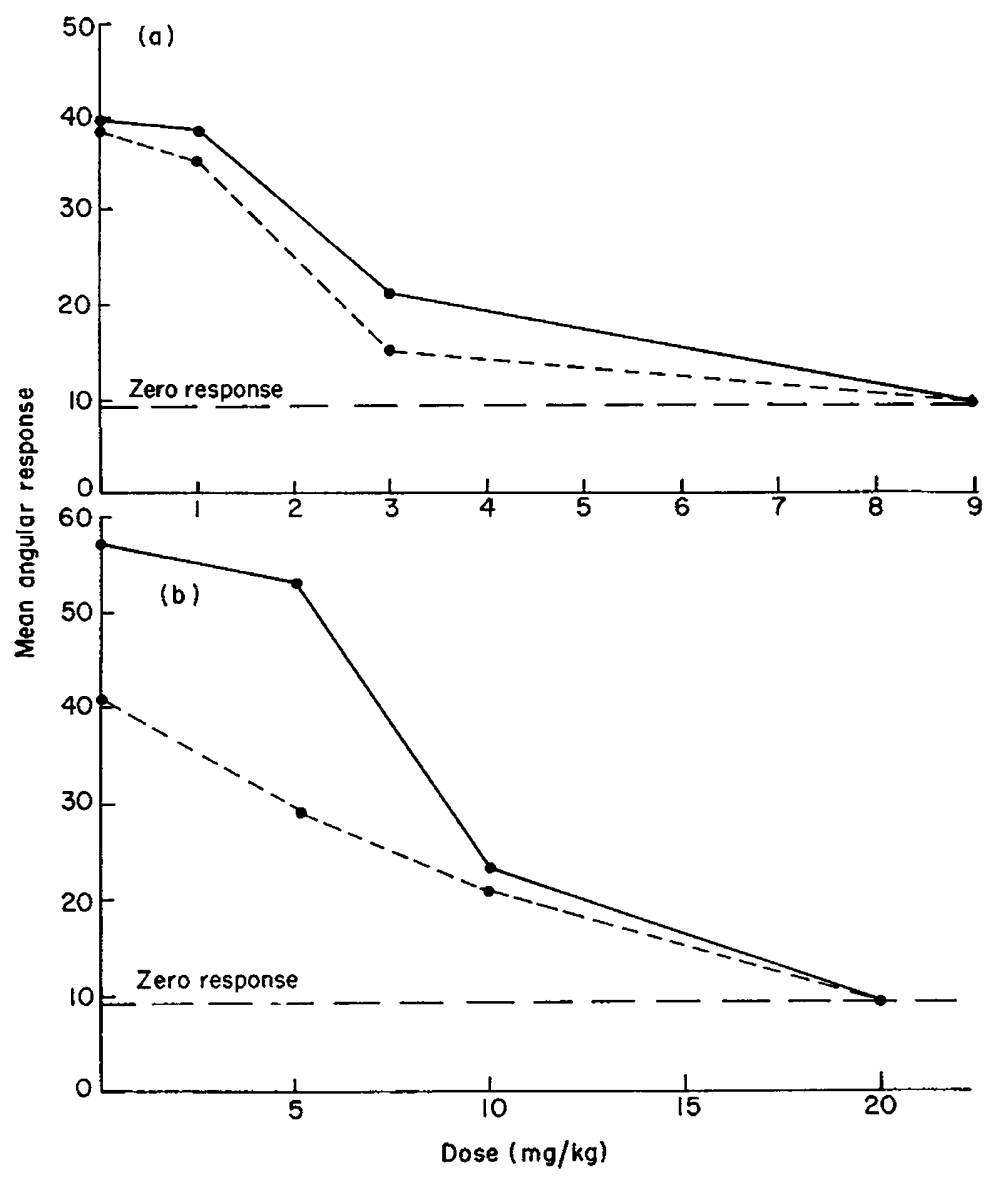

TEXT-FIG. 1. Effect of oral administration of: (a) clomiphene, and (b) U-11555A on pregnancy in mice. - , One dose (Day 2); ---, four doses (Days 1 to 4 ).

experiments any mouse with one or more implanted conceptuses was scored as a positive response, even when the foetuses were in the process of resorption or abortion. The large variation among experiments in the total number of pregnant mice cannot be explained.

A $t$-test was used to compare the mean angular responses of the eight treatments. In the clomiphene experiments there were no significant differences 
TABLE 1

EFFECT OF CLOMIPHENE ON THE DEVELOPMENT OF TWO-CELL EMBRYOS

INTO BLASTOCYSTS in vitro

\begin{tabular}{|c|c|c|c|c|c|c|}
\hline \multirow{2}{*}{$\begin{array}{c}\text { Clomiphene } \\
\text { concentration } \\
(\mu \mathrm{g} / \mathrm{ml})\end{array}$} & \multicolumn{2}{|c|}{$\begin{array}{c}\text { Experiment I } \\
\text { response* }\end{array}$} & \multicolumn{2}{|c|}{$\begin{array}{c}\text { Experiment II } \\
\text { response }\end{array}$} & \multirow{2}{*}{$\begin{array}{c}\text { Mean } \\
\text { percentage } \\
\text { response }\end{array}$} & \multirow{2}{*}{$\begin{array}{l}\text { Mean } \\
\text { angular } \\
\text { response }\end{array}$} \\
\hline & Tube 1 & Tube 2 & Tube 3 & Tube 4 & & \\
\hline $\begin{array}{l}0 \\
0 \cdot 025 \\
0.05 \\
0 \cdot 1 \\
0 \cdot 2 \\
0 \cdot 4 \\
0.8\end{array}$ & $\begin{array}{l}4 \\
3 \\
6 \\
2 \\
1 \\
1 \\
0\end{array}$ & $\begin{array}{l}8 \\
5 \\
0 \\
3 \\
5 \\
0 \\
0\end{array}$ & $\begin{array}{l}6 \\
5 \\
2 \\
2 \\
0 \\
0 \\
0\end{array}$ & $\begin{array}{l}2 \\
3 \\
4 \\
1 \\
3 \\
0 \\
0\end{array}$ & $\begin{array}{c}41 \cdot 7 \\
33 \cdot 3 \\
25 \cdot 0 \\
16 \cdot 7 \\
18 \cdot 7 \\
2 \cdot 1 \\
0\end{array}$ & $\begin{array}{r}39 \cdot 78 \\
35 \cdot 11 \\
28 \cdot 17 \\
23 \cdot 75 \\
23 \cdot 82 \\
10 \cdot 41 \\
8 \cdot 30\end{array}$ \\
\hline
\end{tabular}

ANALYSIS OF VARIANCE

\begin{tabular}{l|c|c|c}
\hline \multicolumn{1}{c|}{ Source of variation } & d.f. & $\begin{array}{c}\text { Mean } \\
\text { square }\end{array}$ & $F$ \\
\hline Between experiments & 1 & $108 \cdot 74$ & $1 \cdot 44$ \\
Between treatments & 6 & $547 \cdot 21$ & $7 \cdot 27 \dagger$ \\
Treatments by experiments & 6 & $26 \cdot 37$ & $<1$ \\
Theoretical variance & $\infty$ & $75 \cdot 3$ & \\
\hline
\end{tabular}

* Response is the number of normal blastocysts formed from twelve two-cell embryos after 3 days in culture.

$\dagger P<0.001$.

TABLE 2

EFFECT OF U-11555A ON THE DEVELOPMENT OF TWO-CELL EMBRYOS INTO BLASTOCYSTS in vitro

\begin{tabular}{|c|c|c|c|c|c|c|c|c|c|c|}
\hline \multirow{2}{*}{$\begin{array}{c}\begin{array}{c}\text { Concentration } \\
\text { of } U-11555 \mathrm{~A} \\
(\mu \mathrm{g} / \mathrm{ml})\end{array} \\
0 \\
2 \cdot 5 \\
5 \cdot 0 \\
10 \cdot 0 \\
20 \cdot 0\end{array}$} & \multicolumn{2}{|c|}{$\begin{array}{c}\text { Experiment I } \\
\text { response* } \\
\begin{array}{cc}\text { Dr. } 1 & \text { Dr. } 2\end{array}\end{array}$} & \multicolumn{2}{|c|}{$\begin{array}{c}\text { Experiment II } \\
\text { response } \\
\text { Dr. } 3 \text { Dr. } 4\end{array}$} & \multicolumn{2}{|c|}{$\begin{array}{c}\text { Experiment III } \\
\text { response } \\
\text { Dr. } 5 \text { Dr. } 6\end{array}$} & \multicolumn{2}{|c|}{$\begin{array}{c}\text { Experiment } I V \\
\text { response } \\
\text { Dr. } 7 \text { Dr. } 8\end{array}$} & \multirow{2}{*}{$\begin{array}{c}\begin{array}{c}\text { Mean } \\
\text { percentage } \\
\text { response }\end{array} \\
70 \cdot 8 \\
64 \cdot 6 \\
55 \cdot 2 \\
24 \cdot 0 \\
0\end{array}$} & \multirow{2}{*}{$\begin{array}{c}\begin{array}{c}\text { Mean } \\
\text { angular } \\
\text { response }\end{array} \\
58 \cdot 29 \\
54 \cdot 11 \\
48 \cdot 06 \\
27 \cdot 83 \\
8.30\end{array}$} \\
\hline & $\begin{array}{r}11 \\
9 \\
5 \\
2 \\
0\end{array}$ & $\begin{array}{r}11 \\
10 \\
8 \\
1 \\
0\end{array}$ & $\begin{array}{l}8 \\
5 \\
8 \\
0 \\
0\end{array}$ & $\begin{array}{l}5 \\
5 \\
6 \\
4 \\
0\end{array}$ & $\begin{array}{l}9 \\
6 \\
7 \\
4 \\
0\end{array}$ & $\begin{array}{r}9 \\
10 \\
6 \\
2 \\
0\end{array}$ & $\begin{array}{l}9 \\
7 \\
5 \\
8 \\
0\end{array}$ & $\begin{array}{r}6 \\
10 \\
8 \\
2 \\
0\end{array}$ & & \\
\hline
\end{tabular}

ANALYSIS OF VARIANCE

\begin{tabular}{l|c|c|c}
\hline \multicolumn{1}{c|}{ Source of variation } & d.f. & $\begin{array}{c}\text { Mean } \\
\text { square }\end{array}$ & $F$ \\
\hline Between experiments & 3 & $157 \cdot 64$ & $2 \cdot 09$ \\
Between treatments & 4 & $3498 \cdot 07$ & $46.46 \dagger$ \\
Treatments by experiments & 12 & $109 \cdot 68$ & 1.46 \\
Theoretical variance & $\infty$ & $75 \cdot 3$ & \\
\hline
\end{tabular}

* Response is the number of normal blastocysts formed from twelve two-cell embryos after 3 days in culture.

$\dagger P<0.001$. 
between the four single-dose treatments and the corresponding quadruple-dose treatments, between the lowest doses and their controls or between the middle and highest doses. The pregnancy responses to the lowest doses and controls were significantly higher $(P<0.05)$ than the responses to the middle and high doses. In the U-11555A experiments there were no significant differences between the single- and multiple-dose treatments for the high and middle doses, but the single-dose group response was significantly higher $(P<0.05)$ than that of the quadruple-dose group for both the lowest treatment dose and the control. In addition, the control responses were significantly higher

TABLE 3

EFFECT OF ORALLY ADMINISTERED GLOMIPHENE ON PREGNANCY MAINTENANCE IN MICE

\begin{tabular}{|c|c|c|c|c|c|}
\hline $\begin{array}{c}\text { Dose of } \\
\text { clomiphene }\end{array}$ & & & & $\begin{array}{c}\text { Mean } \\
\text { percentage } \\
\text { response }\end{array}$ & $\begin{array}{c}\text { Mean } \\
\text { angular } \\
\text { response }\end{array}$ \\
\hline $\begin{array}{l}\text { Control } \\
1 \mathrm{mg} / \mathrm{kg} \\
3 \mathrm{mg} / \mathrm{kg} \\
9 \mathrm{mg} / \mathrm{kg} \\
4 \times \text { control } \\
4 \times 0.25 \mathrm{mg} / \mathrm{kg} \\
4 \times 0.75 \mathrm{mg} / \mathrm{kg} \\
4 \times 2.25 \mathrm{mg} / \mathrm{kg}\end{array}$ & $\begin{array}{l}1 \\
3 \\
1 \\
0 \\
4 \\
0 \\
0 \\
0\end{array}$ & $\begin{array}{l}6 \\
2 \\
2 \\
0 \\
2 \\
4 \\
1 \\
0\end{array}$ & $\begin{array}{l}6 \\
7 \\
1 \\
0 \\
6 \\
7 \\
1 \\
0\end{array}$ & $\begin{array}{c}43 \cdot 3 \\
40 \cdot 0 \\
13 \cdot 3 \\
0 \\
40 \cdot 0 \\
36 \cdot 7 \\
6 \cdot 7 \\
0\end{array}$ & $\begin{array}{r}39 \cdot 99 \\
38 \cdot 86 \\
21 \cdot 14 \\
9 \cdot 10 \\
38 \cdot 86 \\
35 \cdot 04 \\
15 \cdot 32 \\
9 \cdot 10\end{array}$ \\
\hline
\end{tabular}

ANALYSIS OF VARIANCE

\begin{tabular}{l|c|c|c}
\hline \multicolumn{1}{c|}{ Source of variation } & d.f. & $\begin{array}{c}\text { Mean } \\
\text { square }\end{array}$ & $F$ \\
\hline Between experiments & 2 & $484 \cdot 34$ & $5 \cdot 24 \dagger$ \\
Between treatments & 7 & $564 \cdot 37$ & $6 \cdot 11 \ddagger$ \\
Theoretical variance & $\infty$ & $92 \cdot 4$ & \\
\hline
\end{tabular}

* Response is number of mice, out of ten/treatment, with implantations, regardless of number or condition.

$+0.001<P<0.01$.

$¥ P<0.001$.

$(P<0.01)$ than those of the high and middle dose groups, while there were no significant differences between the control groups and the groups receiving the lowest doses.

In studying the effect of the two compounds on the number of implantation sites per pregnant mouse, the large amount of variation involved makes it difficult to evaluate the significance of the data (Table 5). In general, the data suggest that increasing the dose of either compound causes a decrease in the number of implanting embryos per pregnant mouse.

\section{DISCUSSION}

The culture experiments have shown that fairly low concentrations of both antifertility agents interfere with the in-vitro development of pre-implantation 
TABLE 4

EFFECT OF ORALLY ADMINISTERED U-11555A ON PREGNANGY MAINTENANCE IN MICE

\begin{tabular}{|c|c|c|c|c|c|}
\hline $\begin{array}{l}\text { Dose of } \\
U-11555 A\end{array}$ & \multicolumn{3}{|c|}{$\begin{array}{l}\text { * Response by } \\
\text { Experiment } \\
I \quad I I \quad I I I\end{array}$} & $\begin{array}{c}\text { Mean } \\
\text { percentage } \\
\text { response }\end{array}$ & $\begin{array}{l}\text { Mean } \\
\text { angular } \\
\text { response }\end{array}$ \\
\hline $\begin{array}{l}\text { Control } \\
5 \mathrm{mg} / \mathrm{kg} \\
10 \mathrm{mg} / \mathrm{kg} \\
20 \mathrm{mg} / \mathrm{kg} \\
4 \times \text { control } \\
4 \times 1.25 \mathrm{mg} / \mathrm{kg} \\
4 \times 2.5 \mathrm{mg} / \mathrm{kg} \\
4 \times 5 \mathrm{mg} / \mathrm{kg}\end{array}$ & $\begin{array}{l}8 \\
8 \\
1 \\
0 \\
3 \\
0 \\
1 \\
0\end{array}$ & $\begin{array}{l}5 \\
4 \\
1 \\
0 \\
4 \\
3 \\
0 \\
0\end{array}$ & $\begin{array}{l}8 \\
7 \\
3 \\
0 \\
6 \\
5 \\
3 \\
0\end{array}$ & $\begin{array}{c}70 \cdot 0 \\
63 \cdot 3 \\
16 \cdot 7 \\
0 \\
43 \cdot 3 \\
26 \cdot 7 \\
13 \cdot 3 \\
0\end{array}$ & $\begin{array}{r}57 \cdot 29 \\
53 \cdot 15 \\
23 \cdot 36 \\
9 \cdot 10 \\
41 \cdot 07 \\
29 \cdot 10 \\
20 \cdot 25 \\
9 \cdot 10\end{array}$ \\
\hline
\end{tabular}

ANALYSIS OF VARIANCE

\begin{tabular}{l|c|c|c}
\hline \multicolumn{1}{c|}{ Source of variation } & d.f. & $\begin{array}{c}\text { Mean } \\
\text { square }\end{array}$ & \multicolumn{1}{|c}{$F$} \\
\hline Between experiments & 2 & $332 \cdot 41$ & $3.60 \dagger$ \\
Between treatments & 7 & $1035 \cdot 42$ & $11 \cdot 21 \ddagger$ \\
Theoretical variance & $\infty$ & $92 \cdot 4$ & \\
\hline
\end{tabular}

* Response is number of mice, out of ten/treatment, with implantations, regardless of number or condition.

$+0.01<P<0.05$.

$\pm P<0.001$.

TABLE 5

EFFECT OF GLOMIPHENE AND U-11555A ON THE MEAN NUMBER OF IMPLANTATION SITES PER PREGNANT MOUSE

\begin{tabular}{l|c|c|c}
\hline \multicolumn{2}{c|}{ Clomiphene } & \multicolumn{2}{c}{$U-11555 \mathrm{~A}$} \\
\multicolumn{1}{c|}{ Dose } & $\begin{array}{c}\text { Implantation } \\
\text { sites* }\end{array}$ & Dose & $\begin{array}{c}\text { Implantation } \\
\text { sites }\end{array}$ \\
\hline Control & $17 \cdot 2 \pm 5 \cdot 88$ & Control & $14 \cdot 0 \pm 5.40$ \\
$1 \mathrm{mg} / \mathrm{kg}$ & $13 \cdot 0 \pm 6 \cdot 71$ & $5 \mathrm{mg} / \mathrm{kg}$ & $12 \cdot 1 \pm 8 \cdot 04$ \\
$3 \mathrm{mg} / \mathrm{kg}$ & $11 \cdot 3 \pm 8 \cdot 04$ & $10 \mathrm{mg} / \mathrm{kg}$ & $5 \cdot 2 \pm 2 \cdot 71$ \\
$4 \times \mathrm{control}$ & $15 \cdot 9 \pm 5 \cdot 75$ & $4 \times \mathrm{control}$ & $11 \cdot 9 \pm 3 \cdot 52$ \\
$4 \times 0 \cdot 25 \mathrm{mg} / \mathrm{kg}$ & $14 \cdot 1 \pm 8 \cdot 91$ & $4 \times 1.25 \mathrm{mg} / \mathrm{kg}$ & $10 \cdot 9 \pm 3 \cdot 76$ \\
$4 \times 0.75 \mathrm{mg} / \mathrm{kg}$ & $11 \cdot 0 \pm 3 \cdot 00$ & $4 \times 2 \cdot 5 \mathrm{mg} / \mathrm{kg}$ & $6 \cdot 3 \pm 2 \cdot 49$ \\
\hline
\end{tabular}

* The numbers represent the mean number of implanted foetuses/ pregnant mouse and the standard deviation.

mouse embryos. The concentration of clomiphene which prevented blastocyst formation from the two-cell embryo $(0 \cdot 8 \mu \mathrm{g} / \mathrm{ml})$ is much lower than the dose which blocked cleavage of the cultured 1-day rabbit ovum $(0 \cdot 1 \%$; Chang, 1964). It was noted that $0 \cdot 8 \mu \mathrm{g} / \mathrm{ml}$ of clomiphene allowed one or two cleavages in most of the cultured embryos, while the lowest dose of U-11555A which 
completely blocked blastocyst formation $(20 \mu \mathrm{g} / \mathrm{ml})$ also caused rapid degeneration of the two-cell embryos. This difference in effects may indicate either a steeper dose response curve for U-11555A than for clomiphene or an instability of U-11555A under the culture conditions.

The gavaging experiments indicated that the doses of the two agents which completely block pregnancy in mice are somewhat higher than those effective for rats. In rats, the doses of clomiphene which prevent pregnancy are 0.3 $\mathrm{mg} / \mathrm{kg} /$ day for Days 1 to 4 or $0.9 \mathrm{mg} / \mathrm{kg} /$ day on any one of the first 4 days of pregnancy (Nelson et al., 1963). These amounts are one tenth those required to block pregnancy completely in the mouse. With U-11555A, the antifertility doses for rats are $1 \mathrm{mg} / \mathrm{kg} / \mathrm{day}$ for the quadruple dose or $5 \mathrm{mg} / \mathrm{kg}$ for a single dose (Nelson et al., 1963). The effective doses of this compound for the mouse are approximately four times those effective in the rat. On the other hand, the antifertility doses for rabbits appear to be comparable to those for mice (Chang, 1964). Differences between species may represent inherent differences in susceptibility, but could also be due to variations in technical details. For example, the solvent vehicle for administration of the compounds, as well as the method of gavage, differs in studies by different investigators.

In comparing the effects of different regimens, it was found that, for clomiphene, there were no significant differences between the response to single doses and to the equivalent multiple doses. With U-11555A, there were significantly more mice pregnant with the lowest single dose than with the corresponding quadruple dose. Since the same was true of the single- and multiple-dose control groups, however, it is likely that the lower number of pregnancies in the one multiple-dose group was due to the increased amount of handling of the pregnant mice. In general, it appears likely that the multiple doses have an accumulative effect, since the dose response curves for the single doses and the total multiple doses are quite similar. It was also found that the single dose of each compound which completely blocked pregnancy was equally effective on the 1st, 2nd, 3rd or 4th day of pregnancy (J. L. Thomson, unpublished data).

The effect of dose of the compounds on the number of implanting conceptuses suggests that increasing doses of the compounds cause a decrease in the number of implantation sites, although the large amount of variation makes it impossible to draw any definite conclusions. If this were the case, one might suspect that the compounds were causing a reduction in the viability of the embryos.

A comparison of the in-vitro and in-vivo effective doses is difficult, unless one is able to determine the distribution of the in-vivo dose in the body of the mouse, and, in particular, the amounts found in the oviducal and uterine fluids. If one assumes, for purposes of discussion only, that the compounds are distributed equally to all areas of the body, the following rough comparisons can be made. For clomiphene, the effective single in-vivo dose is $9 \mathrm{mg} / \mathrm{kg}$ or $9 \mu \mathrm{g} / \mathrm{g}$, as compared with the effective in-vitro concentration of $0.4 \mu \mathrm{g} / \mathrm{ml}$. A single oral dose of $20 \mathrm{mg} / \mathrm{kg}$ or $20 \mu \mathrm{g} / \mathrm{g}$ of U-11555A was completely effective in blocking pregnancy, while the lowest inhibitory in-vitro dose was $20 \mu \mathrm{g} / \mathrm{ml}$. Thus it is likely that the effective in-vitro and in-vivo doses are at least in the same range of concentrations. On this basis, one cannot eliminate the possi- 
bility that the in-vivo effects of the agents are due to a direct deleterious action on the zygotes. Further studies are now in progress which should determine more clearly the mode of action of the compounds.

\section{ACKNOWLEDGMENTS}

This investigation was supported by a grant from the National Institutes of Health (D-02315-01). Clomiphene was a gift of Dr Dorsey E. Holtkamp of the William S. Merrell Company, and U-11555A was donated by Dr Gordon W. Duncan of the Upjohn Company.

The author gratefully acknowledges the excellent technical assistance of Mrs Peggy Earnest, Mrs Mary Reale and Miss Mary Ryans.

\section{REFERENCES}

BARNes, L. E. \& MEYeR, R. K. (1962) Effects of ethamoxytriphetol, MRL-37, and clomiphene on reproduction in rats. Fert. Steril. 13, 472.

Biggers, J. D. \& Brinster, R. L. (1965) Biometrical problems in the study of early mammalian embryos in vitro. F. exp. Zool. 158, 39.

BRINSter, R. L. (1963) A method for in vitro cultivation of mouse ova from two-cell to blastocyst. Expl Cell Res. 32, 205.

BRInster, R. L. (1965) Studies on the development of mouse embryos in vitro. IV. Interaction of energy sources. F. Reprod. Fert. 10, 227.

Ghang, M. C. (1964) Effects of certain antifertility agents on the development of rabbit ova. Fert. Steril. $15,97$.

Davidson, O. W., Schuckner, E. B. \& Wada, K. (1965) Effect of clomiphene on rat zygotes. Fert. Steril. 16, 495.

Duncan, G. W., Stucki, J. G., Lyster, S. C. \& Lednicer, D. (1962) An orally effective mammalian antifertility agent. Proc. Soc. exp. Biol. Med. 109, 163.

Nelson, W. O., Davidson, O. W. \& WADA, K. (1963) Studies on interference with zygote development and implantation. In Delayed Implantation, p. 183. Ed. A. C. Enders. University of Chicago Press.

Segal, S. J. \& Nelson, W. O. (1961) Anti-fertility action of chloramiphene. Anat. Rec. 139, 273. 